\title{
Tuberculosis in Jayapura: Human Security Threat in International Relations Perspective
}

\author{
Melyana R Pugu, Mariana E Buiney \\ Cenderawasih University, Jayapura, Papua, Indonesia \\ puguratana@yahoo.com, yanabuiney@yahoo.com
}

\begin{abstract}
The concept of human security defines the purpose of human to be free from poverty, free from terror and free from disease. This paper aims to provide an overview of the infectious disease, tuberculosis (TB), as one of the threats to human security in the city of Jayapura. The method used to assess this study is qualitative research method that describes and illustrates findings in the form of data and figures about the disease both by elaborating primary data collection through interviews with staffs and patients in government-funded health care as well as through secondary data libraries, books, journals and the Internet. The results from this study depict that from 2013 to 2015 the number of tuberculosis patients who reported themselves and get treatment and medication in Jayapura city through public health centres had both increased and decreased significantly. This is due to several reasons i.e. the presence of doctors in the health centres that handled the cases, the rise of patients' awareness on the treatments, the availability of drugs for TB patients in clinics and assistance facilitating by USAID in Papua under the auspice of WHO. In the perspective of international relations, the increasing spread of tuberculosis in Jayapura has become the serious threat to human security and this requires crucial intervention of multi-stakeholders including local government through its health department covering the issue of the availability of accessible health centres, doctors and drugs for tuberculosis treatment. This also includes the promotion and raising awareness for local community relating to TB testing and maintaining one's healthy environment.
\end{abstract}

Keywords: Tuberculosis, Human Security, the city of Jayapura

\section{Introduction}

The development of human security concept has been influenced by the emergence of variety of issues and actors in the world today. According to Shinoda, human security deals with two major aspects of freedom or security against the threat of chronic such as famine and repression as well as it also concerns to the protection of the suffering that arises in everyday life. In 1994, United Nations Development Programme (UNDP) in their report on Human Development describes that there are seven (7) categories of human security, i.e. Economic, food, health, environmental, personal, community and political security (UNDP, 1994, p.22). Health issue as one of the element in human security concept becomes the focus of the research. This relies on the data released by the WHO (World Health Organization) regarding to global emergency status in 1993 about the need to increasing vigilance among countries against lethal viruses attacking the nation/state as a result of globalization, including: HIV, AIDS, Zika, Ebola, Avian influenza, Mers, Tuberculosis (TB), and Malaria. It is fully recognized that viruses can be transmitted along with the migration of people from one place to another globally (WHO Report, 2007). One of the contagious diseases that become the focus of this study is Tuberculosis (TB); it was found on March 24, 1882 by a German, Roberth Koch, after finding pathogenic tuberculosis that attacks human's lungs. The disease is air-borne spread and therefore it spreads rapidly throughout the world. Asia and Africa are two most vulnerable continents where most patients with TB bacteria TBC found. In a year, WHO estimates that TB has killed more than 2 million lives. Its estimation states that between 2002 and 2020, approximately 1 billion people will be infected (WHO report, 2007). So, this is a serious threat to human security in the health sector. Furthermore, Indonesia is among the world's highest TB patients after India, China, South Africa and Nigeria as its TB-reported cases reached 1.569 cases/100.000 people in 2015 (Indonesian Ministry of Health report,2015).

The purpose of this research is to get an overview of TB as a threat to Human Security in the city of Jayapura as well as its prevention efforts that have been made by relevant parties in order to minimize and protect people against tuberculosis. Papua, the most eastern region of Indonesia, has several endemic diseases including Tuberculosis, malaria, AIDS, Leprosy and other contagious diseases. TB, eventually, plays its role as it is estimated that every year its cases nor have not decreased in numbers neither diminished, however, in the strategy if TB control globally, it assures that by 2050, the world will have been being free of TB (WHO report, 2007). Based on data published by Indonesian Ministry of Health relating to Case Detection Rate, in 
2011, there were 302 cases / 100,000 people (Indonesian Ministry of Health report, 2015). In other words, there were 9,511 TB cases reported among 29 cities and/or districts in Papua Province. Jayapura City is one of 29 cities that shows the low cure rate (recovery rate) for it only ranged on $24 \%$ in 2010 (Indonesian Ministry of Health report, 2015). In 2013, it was suspected that there were 685 TB cases, as well as it increased to reach 1,569 cases. Meanwhile, in 2015 as the final year of Millennium Development Goals (MDGs), TB cases hit a peak to 1,601 cases (Jayapura City TB Report 2013-2015). This can be so due Papua's endemic state in health. Jayapura as the capital city of Papua Province has its endemic characteristics for contagious diseases. Regardless its noticeable maintained man-built environments, yet the maintenance for health problems caused by human-to-human transmitted disease in urban communities is inevitable disappeared. It is because the phenomenon of TB cases found in Jayapura is an iceberg-like, for it only shows the surface peak yet it has affected other aspects which are mostly unreported (Aleksius, 2014).

\section{Literature Review}

Fukuda-Parr (2003,p.167) in his paper, New Threats to Human Security in the Era of Globalization argues that in human security concept, the well-being and dignity of people are the crucial element. Moreover, this point of view concern to the 'downside risks' that can threaten the well-being of human, both affluent and poor rather than on the protection of national borders. He explains the spread of diseases like HIV/AIDS, Malaria or Tuberculosis has been a serious issue in the world today. For Instance, in the year 2000, World Health Organization reported that every year there are more than 300 million cases of malaria and 60 million people are infected with tuberculosis. Tuberculosis causes two million deaths each year, thus remaining, with HIV/AIDS, the leading infectious cause of adult mortality in the world. Without much more effective control, by 2020 nearly one billion people will be infected and 35 million will die from tuberculosis (Fukuda-Parr, 2003, p.176). According to UNDP in Human Development Report describes seven scopes of human security: First is economic security, related to basic income for individuals; secondly, food security, all people have access to basic food; third is health security means guaranteeing a minimum protection from diseases and unhealthy lifestyles; environmental security, protecting people form natural disaster in short and long term; Fifth is personal security: protecting people from violence; six is community security, means protecting people from the loss of traditional relationships and values, and from sectarian and ethnic violence; the last scope is political security, respects to basic human rights and freedom (UNDP,1994, p.22) .

\section{Methodology}

This research used qualitative method including collecting data, interview and data analyses. Collected data about TB patients and their treatment from several primary health care units/Puskesmas in Jayapura City and Jayapura Health Office report on TB in 2013 to 2015. This research also included USAID report in health services in Papua Province and data from Indonesian Ministry of Health. Further, through interviews, the researchers also gathered data about the awareness of patient with TB to get treatment. Then, data analyses used to know several factors that influence the success of TB treatment and obstacles in eradicating the spread of Tuberculosis in Jayapura (Barry et al., 1998).

\section{Result and Discussion}

In Indonesia, public health services run by the government consists of five levels: Central, Provincial, District/municipality, sub-district and village. In each level, there are several types of health service facilities which elaborate the concept of primary health service. This has been done through primary public health centre (Puskesmas; for further reference, it is stated as PHC) as the basic main health service. This health service is supported by a bottom-up referral system to the upper facilities i.e. hospital in district level, or any other centres that provide secondary healthcare services. In Jayapura, there are several primary health care units and some of them are mentioned as follow :

- Public Health Centre/PHC North Jayapura;

- PHC IMBI;

- $\quad$ PHC Tanjung ria;

- $\quad$ PHC Hamadi;

- $\quad$ PHC Elli Uyo; 
- $\quad$ PHC Kotaraja;

- PHC Abepura;

- PHC Waena;

- PHC Koya Barat;

- PHC Abepantai;

- PHC Skouw;

- PHC Yoka;

- Abepura Hospital;

- Dian Harapan Hospital;

- Muhammadiyah Health Center (MHC);

- Martin Indey Hospital;

- Navy Hospital;

- Provincial Hospital - Jayapura

- Wali Holle

Through its health services, the local government of Jayapura city is considered rather successful in collecting data about TB cases for each sub-district in its territory as well as in conducting regular case reporting. However, the results for TB treatments have not been achieved satisfactory as this can be seen in the bar chart below

Figure 1: Jayapura City TB cases reported from 2013 to 2015

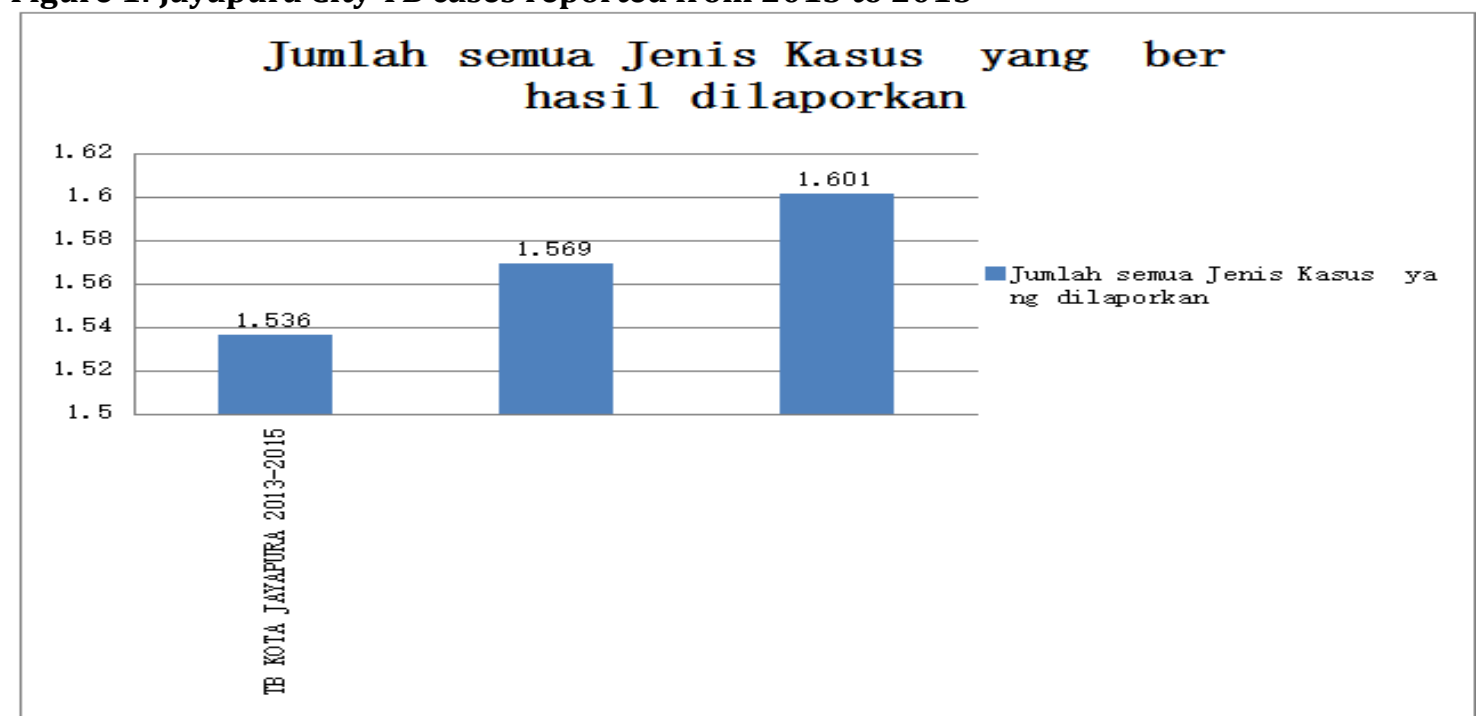

(Source: Primary Data published by Health Office of Jayapura city, TB-case Report 2013-2015)

We can see that Figure 1 depicts the number of all TB-reported cases in 2013-2015 in Jayapura which in its first year (2013), the patients contracted TB were 1,536 people. One year later, this increased to 1,569 with 33 new cases reported. Surprisingly, in 2015, there was a similar increase in number (32 new cases) as the previous year, for the cases reached 1,601. All these numbers in three years consecutively were taken from the patients who reported themselves and undergo medical examinations and have treatment in several PHCs/puskesmas in Jayapura city. This can also be resulted from the rising awareness of TB patients due to the accessible service facilities, for instance, assistance for patients and doctors as well as the availability of TB drugs. Apart from the finding TB cases, in terms of strategy of global prevention for Tuberculosis, one of indicators used is the improvement on DOTS (Directly Observed Treatment Shortcourse). Implementation and strenghthening its qualified expansion. In addition, there is an urgent need to improve case detection and cure rates through focused-patient approach. As a result, this might increase the rate of access for all patients especially the poor and vulnerable ones. On the other hand, Figure 2 shows a reverse finding of the indicator mentioned previously as we can see that the local government in Jayapura has not handled TB cases 
significantly (poor handling) on its treatment (David, 1999). It can be seen from the data shows as for three years mentioned in the chart, the numbers of treatment cases for TB patients remained low

Figure 2: Successfully-treated TB cases

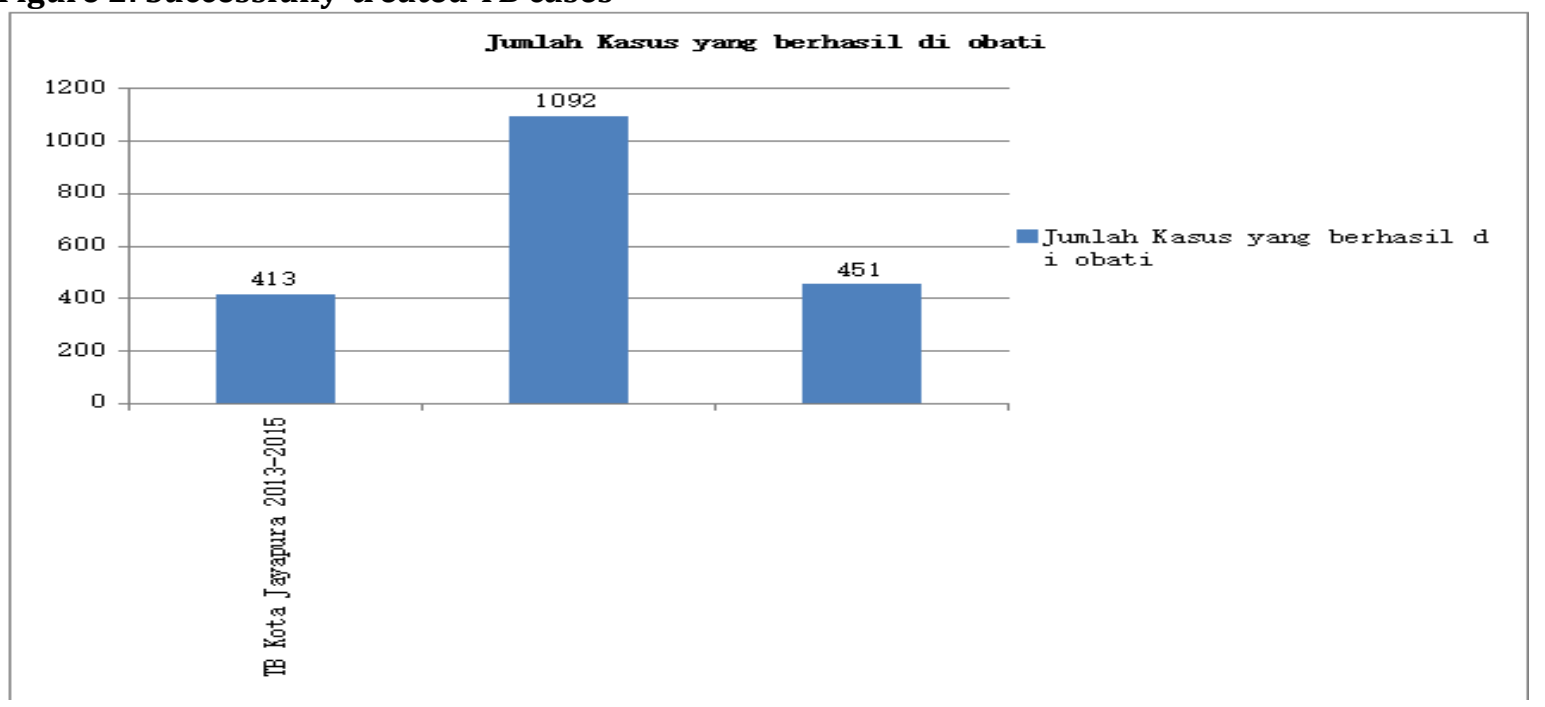

(Source: Primary Data published by Health Office of Jayapura city, TB-case Report 2013-2015)

Based on figure 1.2, we can see that the numbers of TB cases that were successfully treated in Jayapura in three years $(2013$ - 2015). In 2013, there were 413 TB patients treated. Then one year later, the successful TB treatment rocketed to 1,092 which means that there were 679 new fully treated cases within two years. Nevertheless, this rate did not remain longer as in 2015, surprisingly, the number of successful treatment cases fell to 451 cases. The treatment success rate here refers to the number that indicates the percentage of new pulmonary TB patients having bacteriological-confirmed who completed the treatments either cured or complete whilst this was measured by comparing to those recorded new patients with similar cases. So, it can be stated that this figure is the sum of the fully-treated and cured cases. There are several factors that influence the success of TB treatment in Jayapura. They are discussed as follow:

Patient factors: There are three main factors: first, non-adherent patients in taking anti-TB drugs (OAT); second, patients who transferred to another PHC without reporting themselves to either the previous PHC or later (non-referral); third, resistant TB cases to OAT/drugs. These causes usually happen in Jayapura. Another finding also shows the worst scenario of potential transmission caused by half-treated TB patients. This is the reason for the first cause. The frequent cases show that some patients when they realized of TB symptoms accessed the nearest health centres. However, when the treatment has run well and their medical state gradually increased, they tend to stop the treatment. So, the non-adherent cases occured. This may lead to the worst scenario of drugs resistance where patients are not longer can be treated with the previous drugs but they can pose threats to other people. So, the risk of transmission will increase greatly (Luhulima, 2011).

Swallowing-Drugs watchdog factor (PMO): This is the case where the role of supervisor or watchdog is limited. This can be classified into two types: first, the absence of PMO at all; second, PMOs exist but they monitor the treatment less than expected. In this case, members of family and/or patients' inner circle play a crucial role in controlling TB patients in taking drugs regularly. If the role of supervising has not been done effectively until the complete healing, this may lead to the treatment failure and this may pose a threat to others in a greater rate.

Drugs factors: There are several causes in this factors; first, the supply of OAT (Anti TB) is disturbed so that TB patients delay their drugs intake and/or discontinue taking the medication; second, due to the poor storage, the quality of OAT declines. In general, TB drugs are provided for free and can be accessed in public health centres nationwide. Yet, there are several reasons defining patients' discontinuity of undergoing TB 
treatments. One of them is that public awareness in general in accessing TB drugs remains low. This can be caused by either patients' lifestyle and/or mindset, or less supportive environment which somehow all of these lead to high prevalences of this disease. This may eventually lead to greater rate of TB cases and somehow this may pose a threat to human existence. Based on several interviews in Health Office of Jayapura, there is a fact found that TB cases information can be collected through government-funded outreach activities and these cases can be treated. In fact, local government has annually funded TB control programs. Government has adopted WHO's international standard known as DOTS strategy; DOTS refers to Directly Observed Treatment Shortcourse. This strategy emphasizes on direct observation and short-term treatment in detecting and treating TB.

Apart from the most-advanced drug treatments, there are several obstacles found. First, patients' limited knowledge on TB issues. Some patients do not have the awareness of the ongoing dangers of TB pandemic. The frequent cases found are most patients initially postpone their medical visit to any nearest public health centres. Yet, when their TBs are rather severe, patients start to access medical services. This patients' behaviour may lead to less-effective treatment in taking TB drugs. Second, lack of commitment from TB patients during treatment. For TB patients, it is compulsory for them to undergo the treatment between six months to two years depending on the disease severity. However, in reality, there is a tendency of nonadherence for patients in following this treatment. So, there are several cases show the less-frequent drug taking among TB patients as well as the negligence. This may potentially affect to TB spread to others as these patients are still contracting the active TB.

Another obstacle revealed is unhealthy lifestyle, poor nutrition and unhealthy environment. These may act as the contributing factors in TB proliferation. So, for health promotion, government has conducted frequent direct promotions nationwide. This can be in various forms including TB campaigns through mass media and posters on display in public places. Eradicating TB disease may also encounter another delicate obstacle; new TB strain that is resistant for TB drugs in some patients. This can cause rapid growth spread especially when it is airborne transmitted. On the other hand, another hindrance is undetected TB spread due to iceberg phenomenon which one patient may transmit TB bacteria to 10-15 people per annum. This might help to explain TB has not been eradicated yet. So, it needs the commitment and collaboration of multi-parties stakeholders in controlling this disease comprehensively.

\section{Conclusion}

Tuberculosis (TB) has become one of life-threatening human disease, and it is believed that this has killed more than thousands and even millions of people per annum. TB poses a threat to human security because it is a disease that is transmitted through the air. Its characteristics for having easily- grown bacteria is in unhealthy environment. In handling TB cases, it needs the awareness of TB patients as well as supports from Health Office - Jayapura in order to decrease the numbers of people contracting TB. The numbers of all types of tuberculosis cases were reported between 2013-2015 where in 2013 showed that patients in the city of Jayapura were to 1,536 people. In 2014, this increased to 1,569 types of cases. By 2015 the numbers of reported cases were 1601. We can see the increase numbers of TB patients who visited health centres in Jayapura for undergoing examinations and treatments. This may also caused by the improvement on health service facilities including assistance on patients and doctors as well as the drugs availability. There were several TB cases treated successfully in Jayapura in 2013- 2015. In 2013, there were 413 cases, whilst in 2014 there were 1, 092 cases. Yet, this rate declined in 2015 as there were 451 cases treated only. TB treatment success rate is the number that indicates the percentage of new patients having bacteriological confirmed pulmonary TB who completed treatment (either cured or complete treatment) among new TB patients. Thus, this figure is the sum of the numbers and figures of medicine complete cure. In the perspective of international relations, the increasing spread of tuberculosis in the city of Jayapura can pose a serious threat to human security that required serious treatment by stakeholders. This includes local government initiatives through the health department; by providing health centres, doctors and TB drugs. For public, it needs more promotion and raising awareness on the importance of TB testing and maintaining healthy environment. 


\section{Journal of Social and Development Sciences (ISSN 2221-1152)}

Vol. 8, No. 1, pp. 48-53, March 2017

\section{References}

Aleksius, J. (2014). Politik Global, Edisi ke-2. Yogyakarta: Graha Ilmu Press

Barry, B., Weaver, O. \& Wilde, D. (1998). Security: A New Framework for Analysis. London: Lynne Rienner Publisher Inc.

David, M. (1999). Beyond Strategy: Critical Thinking and the New Security Studies," in Contemporary Security and Strategy. A Craig Synder (Ed). London: Macmillan Press Ltd.

Fukuda-Parr, S. (2003). New Threats to Human Security in The Era of Globalization. Journal of Human Development, 4(2), 167-177. Accessed: August, 2016. http://sakikofukudaparr.net/wp

Luhulima. (2011). Dinamika Asia Tenggara Menuju 2015. Yogyakarta: Pustaka Pelajar. Pusat data dan Informasi Kementrian Kesehatan Republik Indonesia. 2015 (Centre of data and information by Ministry of Health, the Republic of Indonesia, 2015) Accessed: August, 2016. www.depkes.go.id/folder/view/01/structure-publikasi-pusdatin-info-datin.html

TB report 2013-2015 in Jayapura City, issued by Health Office in Jayapura

United Nations Development Program (UNDP). (1994). Human Development Report, p.22. Accessed: September, 2016. http://hdr.undp.org/sites/default/files/report.

USAID Report on Health Services in Papua Province. Accessed: August, 2016. http://www.kinerja.or.id/pdf/9fd3d203-139d-4579-aa5d-cd3d5487c4a8.pdf.

World Health Organization Report (WHO). (2007). Accessed: September 2016. www.afro.who.int/index. 